\title{
Perception and Satisfaction toward Mutual Fund Investors in Andhra Pradesh
}

\author{
P.Ratnaraju, V.V.Madhav
}

\begin{abstract}
The present study has been emphasized on the investor's attitude towards mutual fund investments in Andhra Pradesh. The study has categorized the investors in small and large based on the investment criteria. The primary data has been collected and examined with the help of statistical tool of discriminant analysis. The study result stated that the past performance, liquidity and brand equity are the key factors which are playing the vital role in selection of mutual fund schemes for the investments. The investors' expectations have been analyses and the result reveals that the stable portfolio with returns performance. This paper is useful to the stake holders of mutual fund industry such as asset management companies, investors, regulators and fund managers.
\end{abstract}

Keywords: Asset management company, Attitude, Expectations, Investors, Mutual funds and Past

\section{INTRODUCTION}

Attitude is positive or negative reaction towards someone or something. It is an evaluative statement related to people, objects and situations. Attitudes can

be ascertained through either observation or experience. Attitude is comprised of three components cognitive affective and connative. Cognitive component comprises one's belief measured by surveys, interviews, and other reporting methods, affective component signifies feelings such as heart beat, and behavioral component deals with ways of acting towards the object which is direct observation.

Mutual Fund encourages medium and small investors to participate in present financial scenario. The advantages for investors are reducing risk and mobilization of resources and their efficient uses. Due to fluctuations in bank interest rates and unpredictable nature of capital markets, Mutual Fund investment is increasing proportionally

\section{LITERATURE REVIEW}

Ronay and Kim (2006), the paper called attention to that there is no distinction in hazard demeanor between people of various sexual orientation, yet between gatherings of such, guys demonstrate a more grounded tendency to chance resistance. That is, no sexual orientation distinction was found at an individual level, however in gatherings, guys communicated a more grounded expert hazard position than females.

Subhash Chander and Jaspal Singh (2006), the paper examined the inclination of financial specialists, and uncovered that speculator's choice to put resources into a

Revised Manuscript Received on July 22, 2019.

P.Ratnaraju, Research scholar, KLEF (Koneru Lakshmaiah Education Foundation), Vijayawada, A.P. rathna7mba@gmail.com

Dr.V.V.Madhav Associate Professor, KLEF (Koneru Lakshmaiah Education Foundation), Vijayawada, A.P. dr.v.v.madhav@kluniversity.in specific common reserve is influenced by various sources from where data about working of that store ends up accessible to financial specialist. The paper opined that the occupation gatherings vary fundamentally in their observation about the profits got from the shared reserve.

Sorescu and Subramanian (2006) the paper had given a proof that speculators center around the substance of investigator proposals, and don't much consider the ability of the individual making them, which recommends that they may likewise be available to friend impact.

Bodla and Garg (2007), the paper assessed the presentation of 24 development plans of shared assets and uncovered that the vast majority of the plans have beated the market during the investigation time frame as far as return. Be that as it may, the distinction in market return and assets return is discovered immaterial. There exists a moderate positive connection among's hazard and return of the example plans. A vast lion's share of the plans have prevailing with regards to gaining a hazard premium independent of the presentation estimation model concerned. A large portion of the plans have performed superior to the market based on hazard balanced return too.

Hanumantha Rao and Vijay Kr. Mishra, (2007), the examination opined that the Indian Mutual Funds industry has been developing at a solid pace of 16.68 percent for as long as eight years and the pattern will move further. As per the examination, it has been discovered that very nearly $54 \%$ of individuals financial specialists for security and conviction while $38 \%$ of the general population contributes for current spending. Around $53 \%$ of the general population lean toward long haul venture though $23 \%$ individuals each favor medium term and little term speculation.

\section{HYPOTHESES OF THE STUDY}

H0: There is no significant mean difference of Attitude attributes towards mutual fund investments

H0: There is no investor's expectation towards mutual funds investments

The Sample Size: The example information comprises of 172 respondents from value speculators the poll has been confined keeping perspective on 2 destinations for the most part to know the financial specialists demeanor and desires towards shared reserve ventures. The straightforward irregular philosophy has been connected to gather the information.

The device around for information Collection: That information will be gathered through organized questionnaires. It may be so intended. to collect all required information from investors of mutual funds. Based on their knowledge, information source and investment decision factors

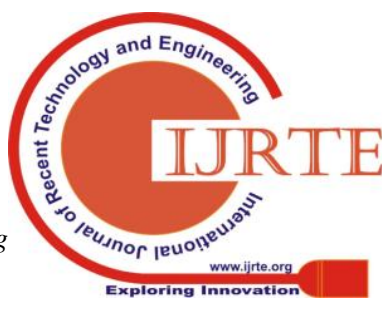


related to the asset management companies and mutual fund schemes.

Tools of Data Analysis: The data and information collected will be classified, tabulated and processed and its findings presented in a systematic manner. Statistical tools as mean difference, " $t$ " test, Discriminant analysis.

\section{TABULATION OF DATA ANALYSIS:}

$1^{\text {st }}$ objective: To study the investors Attitude towards mutual funds' Investments

Table - 1

Factors Influencing to Invest Mutual Funds

\begin{tabular}{|c|c|c|c|c|}
\hline \multirow{2}{*}{ a) $\begin{array}{r}\mathbf{N} \\
\mathbf{0} \\
\text {. }\end{array}$} & \multirow[t]{2}{*}{ b) Factors } & \multicolumn{2}{|c|}{$\begin{array}{c}\text { c)Means Score of the } \\
\text { Investors }\end{array}$} & \multirow{2}{*}{$\begin{array}{ll}\text { d) } & \text { T- } \\
& \text { Statisti } \\
\text { cs }\end{array}$} \\
\hline & & e)Small & f) Large & \\
\hline 1 & Brand Equity & 3.683 & 3.926 & $-1.273^{*}$ \\
\hline 2 & Fund Size & 3.278 & 3.869 & $-2.683 *$ \\
\hline 3 & Type of Funds & 3.571 & 3.725 & -0.836 \\
\hline 4 & $\begin{array}{l}\text { Reputation of } \\
\text { fund manager }\end{array}$ & 4.628 & 4.283 & $3.712 *$ \\
\hline 5 & $\begin{array}{l}\text { Schemes } \\
\text { Portfolio }\end{array}$ & 3.825 & 3.719 & 2.637 \\
\hline 6 & $\begin{array}{l}\text { Liquidity } \\
\text { Factors }\end{array}$ & 3.616 & 2.363 & $4.199 *$ \\
\hline 7 & $\begin{array}{c}\text { Past } \\
\text { performance }\end{array}$ & 3.561 & 3.935 & $-0.627^{*}$ \\
\hline 8 & $\begin{array}{c}\text { Current } \\
\text { market Situations }\end{array}$ & 2.936 & 2.735 & $3.139 *$ \\
\hline 9 & Risk Involved & 3.685 & 3.927 & $-2.635^{*}$ \\
\hline
\end{tabular}

*Significant at Five Percent Level, Source: Primary data

The table -3 depict the significance relative contribution of discriminant factors in which the higher co-efficient is found to be reputation of fund manager with 0.519 followed by liquidity factor and current market situation with 0.386 , 0.377 as their respective discriminant factor co-efficient. This indicates that above factors are more in discriminant function than the other factors. The highest relative contribution is identified in factor past performance with 31.52 followed by 24.61 in liquidity factor and 14.15 in the factor brand equity. By this analysis among the Andhra Pradesh state small and large investors, factors such as past performance, brand equity, liquidity factor and reputation of fund manager are considered to be more important.

$2^{\text {nd }}$ Objective: To study the investors' expectations towards mutual funds

Level of expectation of investors on Mutual Funds varies from small investors to large investors attribute $\&$ is observed through factors such as performance, safety, portfolio, promotion, service quality, reputation, product features analyzed through mean scores among the group of investors with t-statistics and strength of association Wilks lambda have been calculated.

Table -4

Wilks Lambda

\begin{tabular}{|c|c|c|c|c|c|c|}
\hline \multirow{2}{*}{$\begin{array}{l}\mathbf{N} \\
\mathbf{o} \\
.\end{array}$} & \multirow[t]{2}{*}{ Factors } & \multicolumn{2}{|c|}{$\begin{array}{l}\text { Mean Score Among } \\
\text { Investors }\end{array}$} & \multirow[t]{2}{*}{$\begin{array}{r}\text { Mean } \\
\text { Difference }\end{array}$} & \multirow[t]{2}{*}{$\begin{array}{c}\text { T- } \\
\text { Statistical }\end{array}$} & \multirow{2}{*}{$\begin{array}{l}\text { Wil } \\
\text { ks } \\
\text { Lambda }\end{array}$} \\
\hline & & Small & $e$ Larg & & & \\
\hline 1 & $\begin{array}{l}\text { Perform } \\
\text { ance }\end{array}$ & 2.582 & 2.173 & 0.409 & * 2.624 & $\begin{array}{ll} & 0.26 \\
5 & \end{array}$ \\
\hline 2 & Safety & 3.483 & 3.864 & -0.381 & $2^{-2.85}$ & $8 \quad 0.05$ \\
\hline 3 & Portfolio & 3.258 & 2.851 & 0.407 & $\begin{array}{ll} & 2.153 \\
*\end{array}$ & $\begin{array}{ll} & 0.36 \\
5\end{array}$ \\
\hline 4 & $\begin{array}{l}\text { Promoti } \\
\text { on }\end{array}$ & 3.472 & 3.166 & 0.306 & 2.676 & $\begin{array}{lr} & 0.48 \\
8 & \\
\end{array}$ \\
\hline
\end{tabular}

\begin{tabular}{|c|c|c|c|c|c|c|c|}
\hline 5 & $\begin{array}{l}\text { Service } \\
\text { Quality }\end{array}$ & 3.253 & 3.694 & -0.441 & $1 *-2.56$ & 4 & 0.26 \\
\hline 6 & on & 3.614 & 3.265 & 0.349 & $\begin{array}{l} \\
* \quad 2.862\end{array}$ & 6 & 0.01 \\
\hline 7 & $\begin{array}{l}\text { Product } \\
\text { features }\end{array}$ & 3.811 & 3.951 & -0.14 & $8^{*}-2.55$ & 5 & 0.27 \\
\hline
\end{tabular}

* Significant at Five Percent Level.

Source: Primary data

The above table - 4 depicts the small investors level of expectation is high in factors product features, reputation and safety since its mean score are 3.811, 3.614 and 3.483 respectively. The factors product features, safety and service quality for large investors with the means score of 3.951, 3.864 and 3.694 as their significant value is five percent. Regarding the key expectations, the significant difference among the small and large investors have been identified in the case of factors namely reputation, service quality, safety and product feature. Strength of association wilks lambda is considered for expectation of investors on Mutual Funds among all the small and large investors promotion factor is identified to be more with 0.488 in Andhra Pradesh state.

The relative contribution in TDS of factors is analyzed with discriminant co-efficient, mean differences,

Table -5

Discriminant Analysis

\begin{tabular}{|r|c|c|c|c|}
\hline \multicolumn{1}{|c|}{ o. } & Factors & $\begin{array}{c}\text { Discrimin } \\
\text { ant } \\
\text { Coefficie } \\
\text { nt }\end{array}$ & $\begin{array}{c}\text { Mean } \\
\text { Difference }\end{array}$ & $\begin{array}{c}\text { Relative } \\
\text { Contribution } \\
\text { in TDS }\end{array}$ \\
\hline 1 & $\begin{array}{c}\text { Performa } \\
\text { nce }\end{array}$ & 0.385 & 0.409 & 29.65 \\
\hline 2 & Portfolio & 0.286 & 0.407 & 15.84 \\
\hline 3 & $\begin{array}{c}\text { Service } \\
\text { Quality }\end{array}$ & -0.279 & -0.441 & 13.41 \\
\hline 4 & $\begin{array}{c}\text { Reputati } \\
\text { on }\end{array}$ & 0.238 & 0.349 & 22.84 \\
\hline 5 & $\begin{array}{c}\text { Product } \\
\text { features }\end{array}$ & -0.361 & -0.14 & 18.26 \\
\hline & Total & & & 100 \\
\hline
\end{tabular}

Source: Compiled from Primary data

The above table - 5 depicts the higher discriminant coefficient is observed in factors service performance and portfolio as the respective discriminant co-efficient are 0.385 , 0.286 . This analysis indicates that two factors mentioned above are more specific discriminant co-efficient.

The relative contribution in TDS observes to be higher in performance factor (0.385) followed by reputation factor (0.238). The analysis reveals that the performance and reputation factors are major expectations among investors of Andhra Pradesh state investors decisions on Mutual Fund investments.

\section{FINDINGS OF THE STUDY}

The study observed that the factors influencing the mutual fund investments in Andhra Pradesh state

investors, the significance difference among the small and large investors mean score are identified in the case of Liquidity factors (1.253), Reputation of the fund manager (0.345) and past performance $(-0.374)$. 
The Discriminate factor has been applied to identify the most important discriminant factors among the two groups of investors, the higher discriminant power has been identified among the factors are past performance (31.52), Liquidity factor (24.61) and brand equity (14.15).

The study of pooled data result reveals that the important factors which are influencing are past performance (0.612), liquidity factors (0.489), and current market situation (0.386). Thus it states that Andhra Pradesh state mutual fund investors decision making is getting influenced by highly by the past performance.

The investors' expectations have been studied with the discriminant analysis and the result stated that the past Performance and stable portfolio has been indicated with the high discriminate score.

\section{CONCLUSION OF THE STUDY}

The study concludes the attitude of the investors on mutual funds has been studied in the Andhra Pradesh state with mutual fund investors. The present study has categorized the investors into large and small based on the investment criteria. It has considered the investors expectation towards mutual fund. The study had taken up the nine factors relating to the mutual fund investments and collected the data based on likert scale. The $t$ test has been applied to know the mean difference within the factors. The discriminant analysis has been applied to know the attitude of the investors and the result reveals that the past performance of scheme and along with the liquidity is main criteria for the investors. The Andhra Pradesh state mutual fund investors are giving the priority to the brand equity of the mutual fund asset management company. Henceforth there may be a need will would the further investigate in range by acknowledging the observation of the common store moguls of this region, In this way that those stake oversaw economy organizations can comprehend those moguls with propel those new schemes dependent upon the conclusions of the investors'.

\section{REFERENCES}

1. Ronay and Kim (2006), A study on investment preference in mutual fund at Namakkal City, International Journal of Humanities and Social Science Research, ISSN: 2455-2070 Volume 2; Issue 2; February 2006; Page No. 33-36

2. Subhash Chander and Jaspal Singh (2006), Performance Evaluation of Mutual Funds: A Study of Selected Diversified Equity Mutual Funds in India, International Conference on Business, Law and Corporate Social Responsibility (ICBLCSR'14) Phuket (Thailand). Sorescu and Subrahmanyam (2006), Liquidity Risk and Mutual Fund Performance, Journal of Financial Economics 98(1), 54-71.

3. Bodla and Garg (2007), Performance of Equity Schemes of Mutual Funds in India: An Analysis Across Fund Characteristics, https://www.researchgate.net

4. Hanumantha Rao and Vijay Kr. Mishra, (2007), Performance of Private Mutual Funds in India (Comparison of AUM between Mutual Fund Industry and Private Mutual Funds), International Journal on Arts, Management and Humanities, 3(1):1-4 (2014), ISSN No. (Online): 2319-5231. 